\title{
Changes in hard bottom communities related to boat mooring and tributyltin in San Diego Bay: a natural experiment
}

\author{
Hunter S. Lenihan, John S. Oliver, Mark A. Stephenson
}

Moss Landing Marine Laboratories, Moss Landing, California 95039, USA

\begin{abstract}
San Diego Bay contains a number of harbors and other similar-sized embayments. Some contain many boats and others relatively few, providing an unique natural experiment where the ecological impact of mooring many boats was evaluated. Back-bay areas with many boats contained depauperate hard-bottom or fouling communities (less cover, biomass, and fewer species) compared to similar areas in embayments with few boats. Embayments with many boats were characterized by serpulid polychaete worms, filamentous algae, and a solitary tunicate, Ciona intestinalis L. These groups apparently tolerated the physical and chemical stresses associated with many boats, but were replaced by other sessile invertebrates, such as mussels, sponges, bryozoans, and other tunicates, in embayments with few boats. These groups are more characteristic of hard bottom communities on many natural reefs. Unlike the sessile organisms, the motile crustaceans and polychaetes that nestled among the sessile groups were strongly associated with microhabitats, such as patches of algae and dense serpulid mats, rather than the presence of many or few boats. However, there were more species of nestling invertebrates in embayments with few boats. In comparing embayments with many and few boats, sampling was confined to back-bay areas. Hard bottom communities at the front of embayments were similar to back-bay areas where there were few boats. The concentration of tributyltin (TBT, a toxic additive to paint) was also higher in embayments with many boats. We hypothesize that TBT is a cause of the changes in hard bottom communities. Hydrographic variations among embayments with many and few harbors could not explain the consistent community patterns.
\end{abstract}

\section{INTRODUCTION}

Harbors and marinas are complex coastal habitats with many sources of human disturbance. They are commonly contaminated by high levels of toxic anthropogenic chemicals especially oil and gas, organochlorides, and various metals (Capuzzo \& Kester 1987, Phillips 1988). Many harbors and marinas also receive high pulses of freshwater from rivers, agriculture, and urban drainages. The ecosystem effects of changes in salinity, suspended sediments, and anthropogenic chemicals are extremely difficult to separate. Their synergistic effects are almost as difficult to evaluate, because we can rarely locate similar habitats with different levels of contamination or even environmental gradients (but see the pollution gradients in Stull et al. 1986, Swartz et al. 1986, Gray et al. 1988) where most contaminants vary together and important habitat features remain relatively constant.

There are surprisingly few long-term investigations of harbors (see Reish et al. 1980) and no studies documenting the ecological effects of simply mooring many boats in harbors. Although harbors with many and relatively few boats can be located, they are usually separated by large geographic distances and are seldom similar in their general hydrographic environments.

San Diego Bay provides a unique opportunity to evaluate the ecological impacts of many boats. The bay is well flushed by marine-water and is flanked by a number of smaller embayments with generally similar hydrographic settings. The embayments include well flushed mouths and back bay areas with restricted tidal mixing. Largely because of the presence of the US Navy, some of these embayments contain relatively few boats and thus much less input of anthropogenic chemicals associated with large parking, storage, and maintenance areas for boats. No similar group of embayments can be found along the California coast.

This series of embayments with many and few boats provides a rare natural experiment (sensu Connell 
1972, Dayton \& Oliver 1980), where large-scale treatments (many boats) can be contrasted to control areas (few boats) and both can be replicated. Control and replication is accomplished much more accurately and precisely in manipulative field experiments than in most natural experiments, where any control or replication is rare. Nevertheless, natural experiments often occur at realistic spatial scales and can be used to evaluate questions that are impossible to test in more rigorous manipulative experiments (Connell 1972, Dayton \& Oliver 1980, Hurlbert 1984)

The most toxic compound that has been introduced into coastal waters may be tributyltin (TBT), an additive to paint used to kill fouling organisms (Stallard et al. 1987). TBT use on marine boats began in the early 1970 's and became very common during the present decade (Champ \& Lowenstein 1987). TBT is 100- to 1000-times more toxic to laboratory animals than zinc and copper compounds that were previously the main anti-fouling chemicals. Only a few parts per billion kill some organisms (see Thain 1983, U'Ren 1983, Beaumont \& Budd 1984, Valkirs et al. 1985, Walsh et al. 1985, Beaumont \& Newman 1986, Short \& Thrower 1986).

TBI is best known for causing growth deformities in the shells of Pacific oysters and threatening extensive commercial oyster operations (Alzieu et al. 1980, Alzieu 1981, Waldock \& Thain 1983, Stephenson et al. 1986, Thain \& Waldock 1986). The deformation of oysters has occurred in seawater containing TBT in concentrations less than 20 parts per trillion (one trillion $=1 \times 10^{12}$ ) (Stephenson et al. 1988). TBT also influences growth and survival of mussels (Beaumont \& Budd 1984, Salazar \& Salazar 1987, Stromgren \& Bongard 1987), and causes reproductive abnormalities in dogwhelks exposed to concentrations of less than 10 parts per trillion (Gibbs \& Bryan 1986, Bryan et al. 1987, Gibbs et al. 1987). Although TBT occurs in highest concentrations in harbors and marinas (Hall et al. 1986, Cleary \& Stebbing 1987, Langston et al, 1987, Waldock et al. 1987), there are essentially no data on the effects of TBT on natural communities in harbors or in more natural coastal habitats.

This study uses the natural experimental setting in San Diego Bay to test the null hypothesis that marine communities are not influenced by mooring large numbers of boats in an embayment. We focus on hardbottom or fouling communities because they harbor many species and occur throughout the San Diego Bay on similiar substrata. Since high levels of TBT are known from San Diego embayments with many boats (Stang \& Seligman 1986, Valkirs et al. 1986), we also measured the concentration of TBT in water and speculate that this chemical may be important in determining community patterns.

\section{METHODS}

Study sites. San Diego Bay is the second largest coastal embayment in California. It varies from 1 to $4 \mathrm{~km}$ in width and is over $18 \mathrm{~km}$ long with a surface area of $43 \mathrm{~km}^{2}$. The maximum water depth is $21 \mathrm{~m}$ near the entrance, but bottoms exceeding $12 \mathrm{~m}$ in depth cover less than $25 \%$ of the bay's area. In the south bay only dredged channels exceed $4 \mathrm{~m}$ in depth. The bay (Fig. 1) took shape after the last ice age when the San Diego

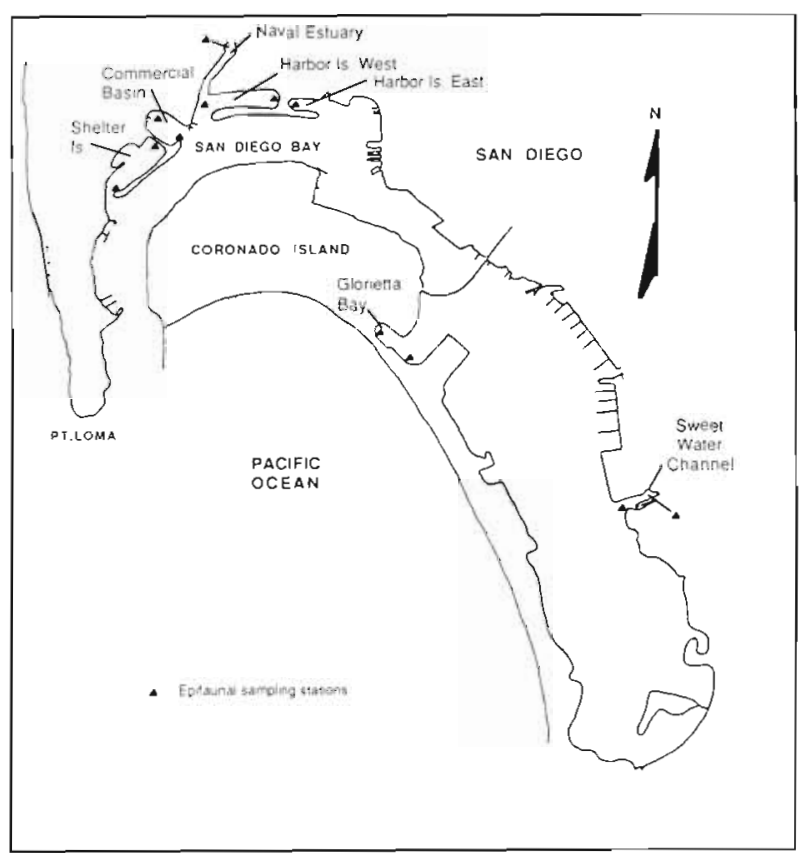

Fig. 1. San Diego Bay showing the embayments with many (Commercial Basin, Shelter Island, Harbor Island West) and few boats (Harbor Island East, Glorietta Bay, Sweetwater Channel, Naval Estuary)

River deposited sediment and debris that joined Point Loma with the mainland and united North Island and Coronado Island. Unfortunately, the river's course was directed to the north during this century and no longer empties into San Diego Bay (Browning \& Speth 1973).

The present bay is tidally flushed by marine waters with seasonal inputs of freshwater that are largely from urban drainages (Browning \& Speth 1973). There are 2 distinct hydrographic regions: the north and south bay (Fig. 1). The north bay is characterized by high rates of flushing and strong tidal currents as great as $150 \mathrm{~cm} \mathrm{~s}^{-1}$ (nearly 3 knots). The north bay contains most of the main shipping channel and dredged areas in the central and western regions (Seligman et al 1986). The south bay is a broad, shallow region where tidal mixing is reduced and water currents are relatively slow The south bay contains much larger areas of intertidal mudflats and vegetated salt marsh than the north bay (Browning \& Speth 1973). 
The main channel of the bay is flanked by many smaller embayments (Fig. 1), whose mouths are relatively well flushed by tidal currents and whose heads contain more isolated water masses. Some of these embayments contain very large numbers of boats and others harbor relatively few (Table 1). The largest

Table 1 Number of boats moored in embayments of different sizes within San Diego Bay (San Diego Unified Port District 1988)

\begin{tabular}{|c|c|c|c|}
\hline San Diego Bay & $\begin{array}{l}\text { No. } \\
\text { boats }\end{array}$ & $\begin{array}{l}\text { No. } \\
\text { boats } \\
\mathrm{km}^{-2}\end{array}$ & $\begin{array}{c}\text { Total area of } \\
\text { embayment } \\
\left(\mathrm{km}^{2}\right)\end{array}$ \\
\hline \multicolumn{4}{|l|}{ Many boats } \\
\hline Commercial Basin & 729 & $2025^{a}$ & 0.353 \\
\hline Shelter Island & 2310 & 3109 & 0.743 \\
\hline Harbor Island West & 1475 & 3580 & 0.412 \\
\hline \multicolumn{4}{|l|}{ Few boats } \\
\hline Harbor Island East ${ }^{\mathrm{b}}$ & $<20$ & $<164$ & 0.122 \\
\hline Glorietta Bay & 320 & 904 & 0.354 \\
\hline Sweetwater Channel & 0 & 0 & 0.160 \\
\hline Naval Estuary & 20 & 70 & 0.285 \\
\hline
\end{tabular}

number of boats are moored in Commercial Basin, Shelter Island, and Harbor Island West. The Sunroad Marina was constructed in Harbor Island East during the present study, increasing the number of boats from less than 20 to almost 300 (Table 1). Since samples were taken when less than 20 boats were present in the harbor, Harbor Island East was called an embayment with few boats. Although there is an intermediate number of boats in Commercial Basin, this embayment contains the highest concentration of boat yards where old paint is removed from hulls and new paint is applied. There is also a large number of boats compared to the aerial cover of the entire basin (Table 1). Commercial Basin, Shelter Island, Harbor Island West and East, Sweetwater Channel, and Naval Estuary were constructed between 1936 and 1961 with significant landfills surrounding the embayments or forming peninsulas enclosing them. Glorietta Bay is the most natural embayment and contains a large water area with relatively few boats (Table 1 ).

All sampling was confined to embayments with many and relatively few boats listed in Table 1 . These embayments were selected after qualitative surveys of hard and soft-bottom communities by SCUBA divers and from floating docks in August 1987. The survey determined the availability of suitable substrates, number of boats and boating activities, and qualitative community patterns. Interviews with boat owners and dock operators regarding the frequency of dock maintenance revealed that disturbances such as periodic cleaning of fouling organisms from float surfaces would not be an uncontrollable variable: the substrates chosen for this study have not been scraped clean for at least $2 \mathrm{yr}$. This survey was part of a larger qualitative survey of marina and harbor communities from Monterey Bay to San Diego Bay.

Final stations were selected by several criteria to minimize habitat variation among embayments. Floating docks and the adjacent pier pilings were located in the extreme backs and fronts of each embayment. Dock substrata were either cement or fiberglass. All of the pier pilings were constructed of cement. All substrata were permanently submerged. Finally, the vertical sides of the dock were large enough for photographic samples.

Many possible sampling sites were eliminated because they did not satisfy the above criteria. The back-bay areas in Harbor Island East and Sweetwater Channel and the front-bay areas at Commercial Basin, Harbor Island West, and Glorietta Bay contained only one appropriate dock. Therefore, in embayments with more than one suitable dock, only one dock was selected at random as the permanent sampling station to keep the spatial scale of the sampling as constant as possible among embayments. Since no suitable hard substrates were present in the front bay areas of Harbor Island East and Sweetwater Channel, and the Harbor Island West und Naval Estuary share the same mouth (Fig. 1), only 4 front-bay stations were located and sampled while 7 back-bay stations were established (Fig. 1).

Quantitative field sampling. Quantitative samples were taken from hard-bottom communities on the vertical sides of floating docks, on the horizontal underside of floating docks, and on the vertical sides of cement pilings. As stated before, all substrates were permanently submerged and undisturbed by tidal movements, boat activities or dock maintenance. The floating docks were either made of cement (Shelter Island and Harbor Island West) or fiberglass.

The percent cover of sessile organisms was estimated from photographs taken by a SCUBA diver with a Nikonis camera and closeup lens, exposing a constant substrate area in each photograph $(24 \times 17 \mathrm{~cm})$. Ten replicate photographs were taken haphazardly (sensu Fager 1968) from each substratum (vertical and horizontal dock and cement piling) at each station. The biomass of sessile organisms, the abundance of nestling animals, and the number of nestling and sessile species were determined from quantitative scrape samples.

The scrape sampler collected all the organisms from an area of $0.0075 \mathrm{~m}^{2}$. It was a coring device with a small 
opening at the top for inserting a sharp blade to scrape organisms off the substrate and into a mesh bag (0.5 $\mathrm{mm}$ openings) attached to the core bottom. A removable jar was attached to the mesh bag, and was removed and emptied above the water after each standard area was scraped and the organisms washed into the jar. A fine-toothed saw blade was coiled around the large open end of the core to cut through attached organisms and precisely defined the sample area. Five replicate scrape samples were taken haphazardly at each station, but only from the vertical surface of floating docks because sample collection was much more difficult from the dock underside and from pilings. Each scrape sample was fixed in $4 \%$ formaldehyde.

In addition, 2 sets of scrape samples of 5 replicates each were taken haphazardly from Commercial Basin in areas with and without a dense growth of filamentous algae. These samples were from the same vertical dock substratum selected for the natural experiment. Sampling was stratified between areas with and without algae because large numbers of nestling infauna appeared to be in algae.

Laboratory sample processing. The percent cover of plants and animals was measured by projecting each photographic slide on a grid containing 100 evenly spaced points. The number of points touching a particular species measured its percent cover. Species were identified to the lowest possible taxon in the photographs with verification from specimens in the scrape samples. Examination of the photographs led to 2 unknown groups: unidentified and 'stuff'. The unidentified group involved any point where photographic quality limited identification and included shadows cast by upright or overhanging organisms, areas out of focus, and over-exposed regions. Stuff was a distinct turf of low growing or smaller organisms and their biogenic structures (such as sediment tubes) that clearly covered the substrate. This growth could be recognized, but not identified to a specific taxon. A dot falling on a species that was growing on another species was recorded for the underlying species. No effort was made to determine the percent cover of species that were blocked by a canopy of organisms in the photographs. This was impractical because of the disturbance caused by removal of canopy species and the difficulty of precisely repositioning the camera for a subsequent understory photograph.

Scrape samples were screened through a $0.5 \mathrm{~mm}$ mesh after preservation in formalin and transferred to $70 \%$ isopropyl alcohol. The major groups and species of sessile organisms were isolated for biomass measurements and all the nestling species were sorted to the lowest possible taxon and counted. The nestling groups were primarily motile polychaete worms and crustaceans. We did not quantify meiofaunal groups such as nematodes and copepods. Serpulid polychaetes were not included in the nestling group because they were sessile and quantified from photographs. Biomass of sessile organisms was measured by standard wet weight. This weight measurement included the calcium carbonate shells of molluscs and serpulid tubes. In addition to abundance, various life history observations were made for the nestling species including size, sex, and reproductive status.

TBT levels. Water samples were collected on 9 August 1987 and 12 January 1988 for determining the concentration of TBT in the back and middle of the 7 embayments sampled for community patterns (Fig. 1). Samples were taken at a water depth of $0.3 \mathrm{~m}$ during a period of high tide, when there was less than a $60 \mathrm{~cm}$ change in tidal height. Tidal currents are known to influence TBT levels in harbor waters (Clavell et al. 1986). Polycarbonate sample bottles were washed with RBS cleaning solution before sampling. Water samples were stored in ice, frozen within $18 \mathrm{~h}$ of collection, and analyzed by hydride derivitization as described in Valkirs et al. (1986). The sampling of TBT in water was part of a larger sampling effort throughout San Diego Bay (Stephenson et al. 1988).

\section{RESULTS}

\section{Back-bay stations}

Sessile organisms

There was a large difference in the percent cover of most sessile organisms found in embayments with many boats compared to those with few (Table 2, Figs. 2 and 3). Only the cover of serpulid polychaetes (primarily Hydroides sp.) was significantly greater (Mann-Whitney U-test, $\mathrm{p}<0.05, \mathrm{n}=3, \mathrm{n}=4$ ) where there were many boats with an average cover of $35 \%$ compared to $2.5 \%$ with few boats (Fig. 2). Hydroides sp. live in a thick, calcareous tube and are common on docks, pier pilings, and boat hulls especially in Southern California (Light 1975, Ricketts et al. 1985). The tubes are often coiled on the substrate at low densities and grow straight into the water at high densities. The tube mat was densest at Shelter Island, where the tubes extended as much as $7 \mathrm{~cm}$ from the substrate. The percent cover of serpulids was not highest at Shelter Island because of the high cover of overstory algae. However, the biomass of serpulids was extremely high there (Fig. 4).

Although the cover of algae was generally higher with many boats, the difference was not significant (Mann-Whitney U-test, $\mathrm{p}>0.05 \mathrm{n}=3, \mathrm{n}=4$ ) because one area with few boats, Harbor Island East, contained a high cover of filamentous red algae, Polysiphonia sp. 

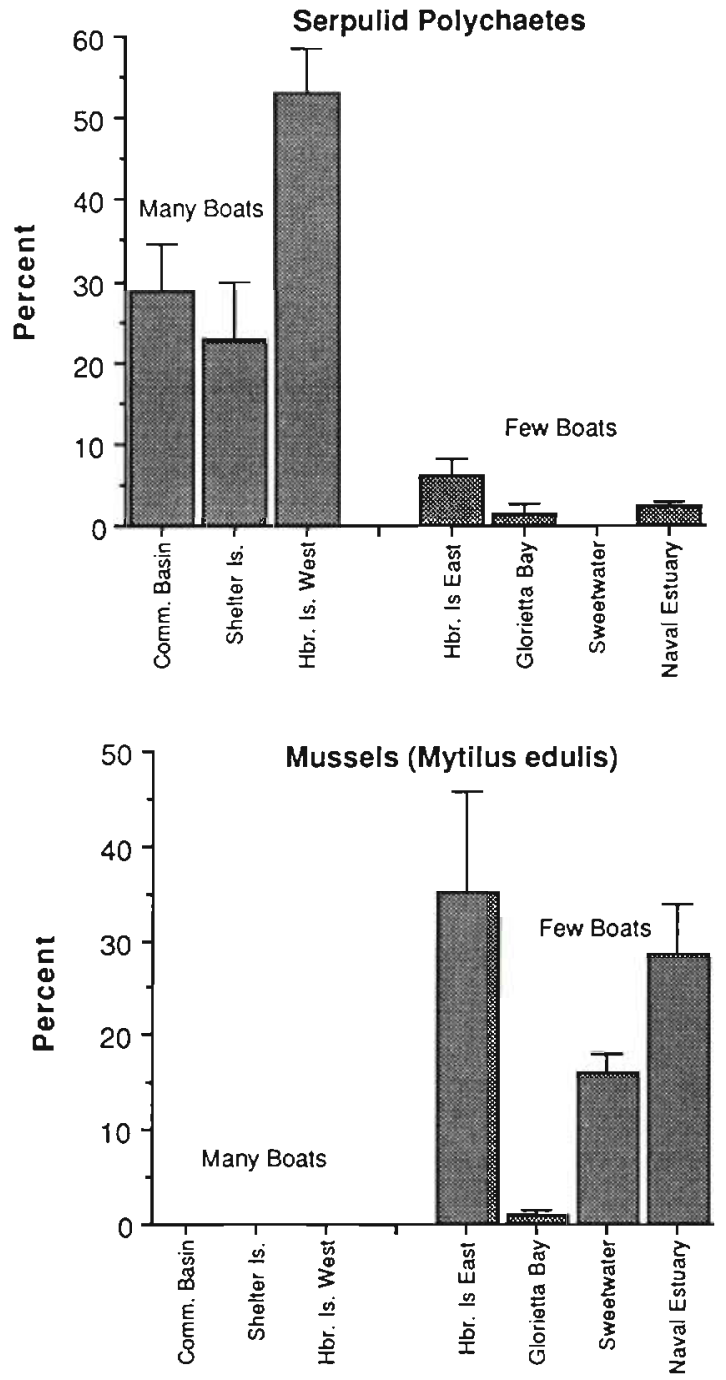

Fig. 2. Changes in percent cover of serpulid polychaete worms (top) and mussels (bottom) from hard bottom communities in San Diego Bay embayments with many and few boats. Means and standard errors based on 10 replicate photographic samples per site
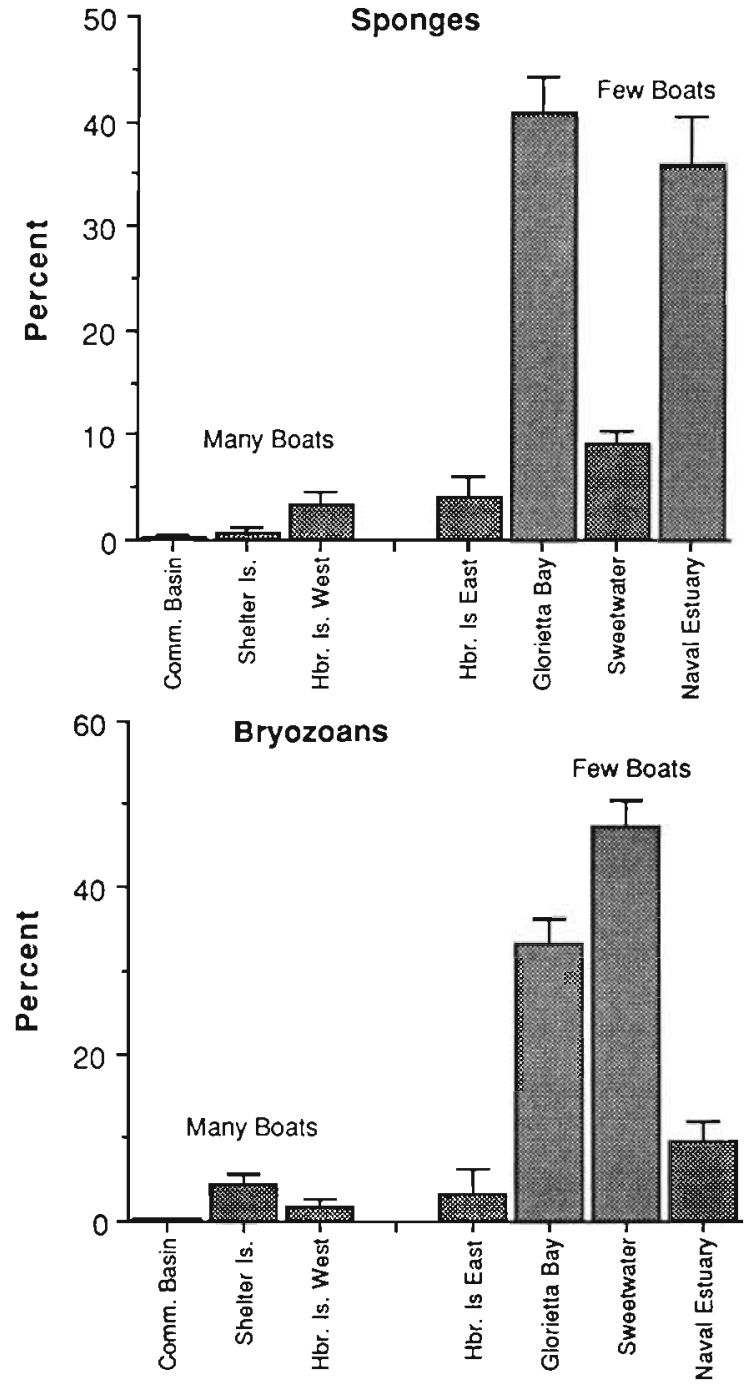

Fig. 3. Changes in percent cover of sponges (top) and bryozoans (bottom) from hard bottom communities in San Diego Bay embayments with many and few boats. Means and standard errors based on 10 replicate photographic samples per site

Table 2. Percent cover of sessile organisms from hard bottom communities in San Diego Bay embayments with many and few boats. Means and standard deviations based on 10 replicate photographs per site. Sites are CB: Commercial Basin; SI: Shelter Islānd; HIW: Harbor Island West; HIE: Harbor Island East; GB: Glorietta Bay; SC: Sweetwater Channel; NE: Naval Estuary

\begin{tabular}{|lccccccc|}
\hline Taxon & \multicolumn{3}{c}{ Many boats } & \multicolumn{3}{c|}{ Few boats } \\
& CB & SI & HIW & HIE (past) & GB & SC & NE \\
\hline Algae & $45.8 \pm 18.0$ & $43.6 \pm 29.6$ & $19.1 \pm 24.1$ & $30.1 \pm 38.3$ & 0 & 0 & $0.1 \pm 0.3$ \\
Sponges & $0.2 \pm 0.6$ & $0.8 \pm 1.3$ & $3.4 \pm 3.7$ & $4.0 \pm 5.9$ & $40.9 \pm 10.4$ & $9.1 \pm 3.7$ & $35.4 \pm 14.8$ \\
Solitary tunicates & $0.8 \pm 1.6$ & $8.6 \pm 14.1$ & $3.5 \pm 4.2$ & $0.1 \pm .32$ & $0.9 \pm 1.9$ & $5.3 \pm 2.8$ & $5.2 \pm 2.2$ \\
Colonial tunicates & $2.4 \pm 5.8$ & $6.7 \pm 7.3$ & $4.6 \pm 4.9$ & $0.8 \pm 1.9$ & $10.3 \pm 7.6$ & $3.0 \pm 1.9$ & $9.1 \pm 2.2$ \\
Total tunicates & $3.2 \pm 6.5$ & $15.3 \pm 16.4$ & $8.1 \pm 5.4$ & $0.9 \pm 1.9$ & $11.1 \pm 8.7$ & $8.3 \pm 3.5$ & $14.3 \pm 6.1$ \\
Upright bryozoans & 0 & $4.4 \pm 3.5$ & $1.8 \pm 3.0$ & $3.1 \pm 9.8$ & $31.4 \pm 9.5$ & $23.0 \pm 11.6$ & 0 \\
Encrusting bryozoans & $0.2 \pm .6$ & 0 & 0 & $0.1 \pm 0.3$ & $1.8 \pm 1.7$ & $24.3 \pm 8.8$ & $9.5 \pm 7.7$ \\
Total bryozoans & $0.2 \pm .6$ & $4.4 \pm 3.5$ & $1.8 \pm 3.0$ & $3.2 \pm 10.1$ & $33.2 \pm 9.5$ & $47.3 \pm 9.9$ & $9.5 \pm 7.7$ \\
Hydroids & 0 & 0 & 0 & 0 & 0 & 0 & $1.0 \pm 1.6$ \\
Serpulids & $28.7 \pm 18.1$ & $22.9 \pm 22.4$ & $53.0 \pm 17.5$ & $6.1 \pm 6.6$ & $1.6 \pm 2.8$ & 0 & $2.2 \pm 2.1$ \\
Molluscs & 0 & 0 & 0 & $41.1 \pm 32.3$ & $1.0 \pm 11.9$ & $16.2 \pm 5.6$ & $31.3 \pm 16.7$ \\
\hline
\end{tabular}




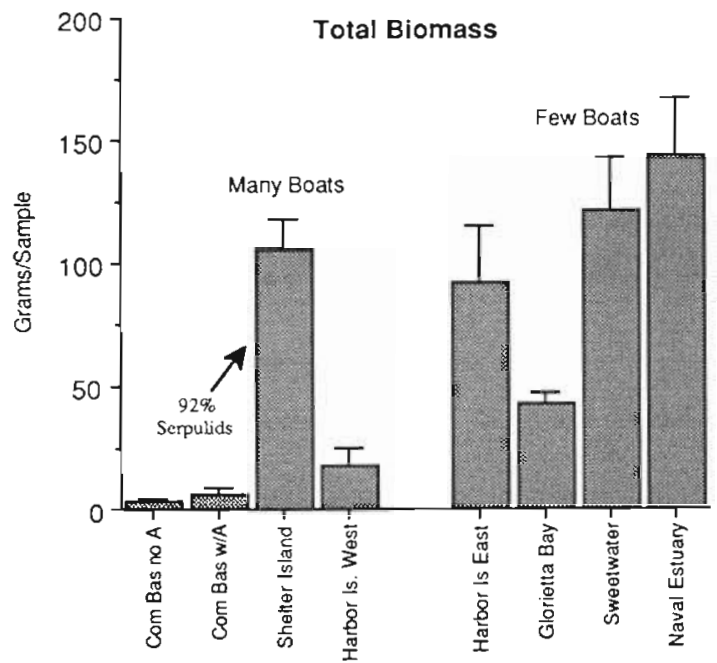

Fiq. 4. Changes in total biomass of sessile organisms from hard bottom communities in San Diego Bay embayments with many and few boats. Means and standard errors based on 5 replicate scrape $\left(0.0075 \mathrm{~m}^{2}\right)$ samples per site

(Table 2). Coincident with this high algal cover was the construction of a new marina in Harbor Island East (only a few boats were moored in the marina) (Table 1). Although there was a high percent cover of macroalgae in several embayments (Table 2), the biomass of algae was rarely high (Table 3 ).

Mussels, sponges and bryozoans (total and encrusting; see Table 2), had significantly greater (Mann-Whitney U-test, $\mathrm{p}<0.05, \mathrm{n}=3, \mathrm{n}=4$ ) cover in embayments with few boats (Table 2, Figs. 2 and 3). The mussel Mytilus edulis L. did not occur in back embayments with many boats (Fig. 2). The average cover of sponges was $22 \%$ in embayments with few boats compared to $1.5 \%$ in those with many (Fig. 3). The most abundant sponges included Hymeniacidon sp., Halichondria bowerbankia Bowerbank, Haliclona sp., Leucetta losangelesis De Laubenfels and Cliona sp. The bryozoans showed the same pattern as sponges (Fig. 3). The most abundant bryozoan species was Hippodiplosia insculpta Hincks, which accounted for almost $40 \%$ cover in Sweetwater Channel. Schizoporella unicornis Johnston, Dendrobeania sp., Membranipora sp. and Bugula neritina L. were also encountered.

Tunicates and upright bryozoans were the only major groups of sessile organisms that showed no distinct pattern in percent cover between embayments with many and few boats (Table 2). The large solitary species, Ciona intestinalis L., was common in Harbor Island West and especially in Shelter Island. It often appeared as a conspicuous indicator of embayments with many boats in association with the serpulid polychaetes. Although $C$. intestinalis accounted for little cover on the vertical hard bottoms in Commercial Basin (Table 2), it was abundant on the horizontal undersurface of the floating docks here. The other tunicate species showed no consistent abundance pattern in relation to many and few boats. Other common solitary species were Styela clava Herdman, S. truncata Ritter, S. montereyensis Dall and S. plicata Lesueur. The most common colonial tunicates included Aplidium solidum Ritter \& Forsyth, A. californicum Ritter \& Forsyth, Archidistoma molle Ritter, A. psammion Ritter \& Forsyth, Botrylloides spp, and Botryllus spp. In contrast to percent cover (Table 2), there was a significantly higher (Mann-Whitney U-test, $\mathrm{p}<0.05 \mathrm{n}=3$, $\mathrm{n}$ $=4$ ) biomass of tunicates in embayments with few boats (Table 3). The upright bryozoan Bugula neritina L. was found in embayments with many boats and few boats. It accounted for a substantial amount of cover in Glorietta Bay and Sweetwater Channel (Table 2). However, due to the delicate and folios morphology of $B$. neritina this organism did not account for much biomass (Table 3 ).

The changes in biomass between embayments with many and few boats were similar to the changes in

Table 3. Biomass of sessile organisms from hard bottom communities in San Diego Bay embayments with many and few boats. Means and standard deviations based on 5 replicate scrape samples per site $\left(0.0075 \mathrm{~m}^{2}\right)$. $-\mathrm{A}$ : no algae; +A: with algae; other abbreviations as in Table 2

\begin{tabular}{|c|c|c|c|c|c|c|c|c|}
\hline \multirow[t]{2}{*}{ Taxon } & \multicolumn{4}{|c|}{ Many boats } & \multicolumn{4}{|c|}{ Few boats } \\
\hline & $C B(-A)$ & $C B(+A)$ & SI & Hrw & HIE & $\mathrm{GB}$ & $\mathrm{SC}$ & NE \\
\hline Algae & 0 & $4.3 \pm 3.4$ & 0 & $0.1 \pm 0.2$ & $0.4 \pm 0.4$ & $1.6 \pm 0.8$ & 0 & 0 \\
\hline Sponces & 0 & 0 & $0.4 \pm 0.5$ & $0.1 \pm 0.1$ & $0.01 \pm 0.02$ & $1.5 \pm 0.9$ & $2.7 \pm 2.9$ & $3.8 \pm 3.0$ \\
\hline Solitary tunicates & $1.4 \pm 2.3$ & $2.3 \pm 2.2$ & $8.2 \pm 8.2$ & $0.5 \pm 0.6$ & $35.9 \pm 22.8$ & $24.9 \pm 7.0$ & $15.8 \pm 10.3$ & $29.5 \pm 44.2$ \\
\hline Colonial tunicates & $1.4 \pm 1.5$ & 0 & $\overline{0}$ & $0.1 \pm 0.1$ & $0.1 \pm 0.3$ & $1.4 \pm 1.8$ & $0.02 \pm 0.04$ & 0 \\
\hline Total tunicates & $3.7 \pm 2.5$ & $2.3 \pm 2.2$ & $8.2 \pm 8.2$ & $0.6 \pm 0.5$ & $36.1 \pm 22.7$ & $26.4 \pm 7.7$ & $15.9 \pm 10.3$ & $29.5 \div 44.2$ \\
\hline Upright bryozoans & 0 & 0 & 0 & 0 & 0 & $0.7 \pm 0.6$ & $1.6 \pm 3.0$ & $0.2 \pm 0.4$ \\
\hline Encrusting bryozoans & 0 & 0 & $0.05 \pm 0.1$ & $0.2 \pm 0.3$ & $1.4 \pm 1.8$ & $0.02 \pm 0.04$ & $42.3 \pm 27.8$ & $1.9 \pm 1.5$ \\
\hline Total bryozoans & 0 & 0 & $0.05 \pm 0.1$ & $0.2 \pm 0.3$ & $1.4 \pm 1.8$ & $0.7 \pm 0.6$ & $43.9 \pm 28.2$ & $2.2 \pm 1.8$ \\
\hline Hydroids & 0 & 0 & 0 & 0 & 0 & 0 & 0 & $\overrightarrow{0}$ \\
\hline Serpulids & $0.1 \pm 0.3$ & 0 & $97.1 \pm 21.6$ & $17.0 \pm 15.5$ & 0 & 0 & 0 & 0 \\
\hline Molluscs & 0 & 0 & 0 & 0 & $40.6 \pm 70.0$ & $9.9 \pm 10.5$ & $57.4 \pm 50.5$ & $101.1 \pm 46.3$ \\
\hline
\end{tabular}


percent cover with several conspicuous exceptions Algae accounted for little biomass (Table 3) but high percent cover (Table 2), forming canopies that covered some understory species in the photographs. Solitary tunicates accounted for high biomass (Table 3 ) and low percent cover (Table 2), because their shortest dimension was usually revealed in the photographs and they were often overgrown by other species. The biomass of sessile organisms was dominated by solitary tunicates and molluscs, primarily mussels (Table 3). When the high biomass of serpulid polychaetes was excluded from Shelter Island, there was a significantly greater (Mann-Whitney U-test, $\mathrm{p}<0.05, \mathrm{n}=3, \mathrm{n}=4$ ) biomass of all sessile groups in embayments with few boats compared to many boats (Fig. 4).

The basic changes in community structure between embayments with many and few boats were observed on all 3 substrates: vertical face and horizontal undersurface of floating docks and the vertical surface of cement pilings. Although only the photographs of vertical dock surfaces were quantified, the other 2 substrates were observed and photographed by divers and the photographs were qualitatively examined in the laboratory. There were a number of changes in community structure among the different substrates, but the changes between embayments with many and few boats still persisted. Our qualitative survey of embayments north of San Diego Bay also revealed the dominance of serpulid polychaetes and filamentous algae in harbors and marinas with many boats and the low cover of other sessile invertebrate groups such as sponges, bryozoans, mussels, and tunicates (also see Stallard et al. 1987). A copy of all the raw community data can be obtained from the authors.

\section{Nestling fauna}

The nestling fauna consisted of motile crustaceans and worms that lived among the sessile organisms. The
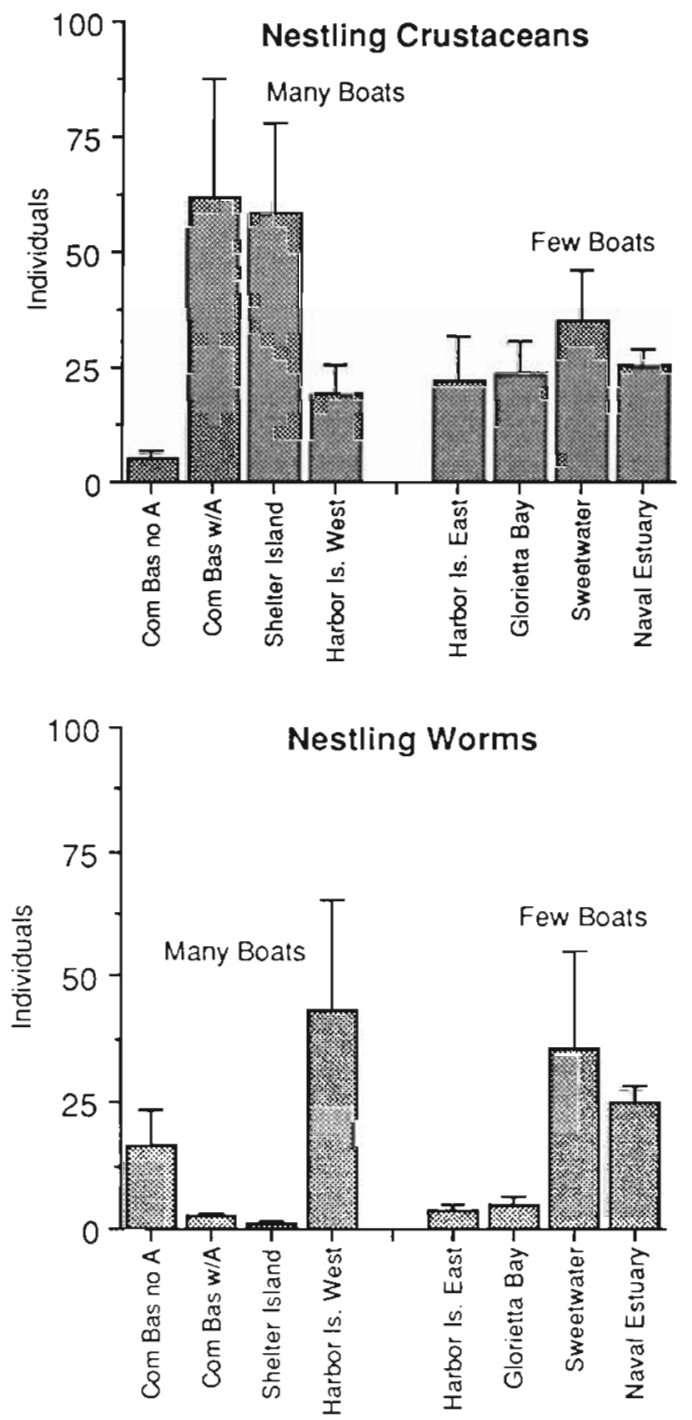

Fig. 5. Changes in the number of nestling crustaceans and worms (primarily polychaetes) from hard bottom communities in San Diego Bay embayments with many and few boats. Means and standard errors based on 5 replicate scrape $\left(0.0075 \mathrm{~m}^{2}\right)$ samples per site

Table 4. Most abundant crustaceans, amphipods and isopods, nestling in the hard bottom communities of embayments with many and few boats. Mean number per scrape sample and standard deviations ( $\mathrm{n}=5$ replicates per site). $-\mathrm{A}$ : no algae; $+\mathrm{A}$ : with algae; other symbols as in Table 2

\begin{tabular}{|c|c|c|c|c|c|c|c|c|}
\hline \multirow[t]{2}{*}{ Species } & \multicolumn{4}{|c|}{ Many boats } & \multicolumn{4}{|c|}{ Few boats } \\
\hline & $\mathrm{CB}(-\mathrm{A})$ & $C B(+A)$ & SI & HIW & HIE (past) & $\mathrm{GB}$ & $\mathrm{SC}$ & NE \\
\hline Elasmopus rapax & $2 \pm 2$ & $52 \pm 52$ & $30 \pm 28$ & $11 \pm 8$ & $4 \pm 6$ & 0 & $11 \pm 17$ & $5 \pm 4$ \\
\hline Leucothoe alata ${ }^{a}$ & 0 & $0.2 \pm 0.4$ & $16 \pm 14$ & $1 \pm 1$ & $0.8 \pm 2$ & $9 \pm 9$ & $0.4 \pm 0.5$ & $1 \pm 1$ \\
\hline Ischyrocerus sp. & $2 \pm 2$ & $3 \pm 14$ & 0 & $\overline{0}$ & 0 & 0 & 0 & 0 \\
\hline Microjassa sp. & 0 & 0 & $1 \pm 1$ & 0 & $3 \pm 3$ & $1 \pm 2$ & $6 \pm 4$ & 0 \\
\hline Aoroides sp. & 0 & 0 & $1 \pm 1$ & $4 \pm 7$ & $4 \pm 6$ & $1 \pm 3$ & 0 & $0.4 \pm 1$ \\
\hline Cyathura sp. ${ }^{c}$ & $1 \pm 1$ & $3 \pm 4$ & $7 \pm 7$ & $3 \pm 4$ & $4 \pm 4$ & $1 \pm 1$ & $3 \pm 3$ & $8 \pm 6$ \\
\hline \multicolumn{9}{|c|}{ "Motile amphipods } \\
\hline \multicolumn{9}{|c|}{${ }^{b}$ A tube-dwelling amphipod } \\
\hline A motile isopod & & & & & & & & \\
\hline
\end{tabular}


most abundant crustaceans were nestling species that did not build and maintain tubes, except Aoroides sp. (Table 4). The crustaceans often swam into the water when the substrate was disturbed, and were easily observed either on the substrate or swimming. Since all the peracarid crustaceans brood their young in a ventral marsupium, the extremely large numbers of small Elasmopus rapax Barnard, Leucothoe alata Barnard and Paracerceis sp. occurring in 1 or 2 samples were probably young that were released from the marsupium during sample procurement or preservation.

Over $98 \%$ of the worm individuals were polychaetes including cirratulids, syllids, and dorvellids that also did not live in tubes. They were not easily observed in the field. Serpulid polychaetes were not included among the nestling groups, because they were attached to the substrate and quantified from the photographic and biomass samples.

Aside from crustaceans and worms there were no other macrofaunal taxon, such as gastropods and fish, found in scrape samples from the different embayments.

The relative abundance of the nestling fauna showed no consistent pattern in relation to embayments with many and few boats (Fig. 5). There was broad overlap in the abundances of nestling crustaceans and polychaete worms from the 2 types of embayments. However, the greatest number of crustaceans were found in Shelter Island and Commercial Basin (Fig. 5). These are embayments containing large numbers of boats (Table 1).

The abundances of nestling crustaceans were related to micro-habitats formed by sessile organisms. The association with microhabitat is clearly illustrated by scrape samples taken in Commercial Basin with and without filamentous red algae Polysiphonia sp., growing in dense patches often 5 to $10 \mathrm{~cm}$ in diameter. The samples with algae contained significantly greater
(Mann-Whitney U-test, $\mathrm{p}<0.05, \mathrm{n}=5$ ) numbers of crustacean individuals than samples without algae (Fig. 5 and Table 4). The dense serpulid tube mat at Shelter Island contained a similarly high number of crustaceans (Fig. 5). Recall that the tube mat at Harbor Island West had a higher percent cover but much less biomass than the tube mat at Shelter Island (Tables 2 and 3, Fig. 4). Large numbers of crustaceans were also observed by SCUBA divers in the algal patches and dense serpulid mats ( $7 \mathrm{~cm}$ thick).

\section{Species patterns}

In contrast to relative abundance patterns, the total number of nestling crustacean and worm species was significantly greater (Mann-Whitney U-test, $\mathrm{p}<0.05$, $\mathrm{n}=3, \mathrm{n}=4$ ) in the embayments with few boats (Table 5). In addition, the highest number of nestling species in embayments with many boats occurred in the microhabitats harboring the largest number of individuals: the algal patches at Commercial Basin and the serpulid forest at Shelter Island (Fig. 5 and Table 5). There was a significantly greater (Mann-Whitney Utest, $\mathrm{p}<0.05, \mathrm{n}=3, \mathrm{n}=4$ ) number of sessile species, and total species in embayments with few boats compared to embayments with many boats (Table 5 ).

\section{Front-bay stations}

The percent cover of sessile organisms from the 4 front-bay stations was similar to that described for the back-bay stations with few boats (compare Fig. 6 to Fig. 3 and 4). Sponges, bryozoans, mussels, and tunicates were major components of the front-bay fauna (Fig. 6). In contrast, organisms that were common in back-bay areas with many boats were rare at

Table 5. Total number of species (sp.) of nestling invertebrates (crustaceans and worms) and total number of species (algae, sessile and nestling invertebrates) from hard bottoms in embayments with many and few boats. Data from scrape samples combining all 5 replicates per site

\begin{tabular}{|c|c|c|c|c|c|}
\hline Embayment & Worms & Crustaceans & $\begin{array}{c}\text { Total } \\
\text { nestlers }\end{array}$ & $\begin{array}{c}\text { Total } \\
\text { sessile sp. }\end{array}$ & $\begin{array}{c}\text { Total } \\
\text { sp. }\end{array}$ \\
\hline \multicolumn{6}{|l|}{ Many boats } \\
\hline Commercial Basin, no algae & 3 & 3 & 6 & 3 & 9 \\
\hline Commercial Basin, with algae & 7 & 9 & 16 & 3 & 19 \\
\hline Shelter Island & 4 & 9 & 13 & 4 & 17 \\
\hline Harbor Island West & 4 & 4 & 8 & 9 & 17 \\
\hline \multicolumn{6}{|l|}{ Few boats } \\
\hline Harbor Island East & 8 & 11 & 19 & 14 & 33 \\
\hline Glorietta Bay & 5 & 13 & 18 & 19 & 37 \\
\hline Sweetwater Channel & 9 & 12 & 21 & 14 & 35 \\
\hline Naval Estuary & 12 & 11 & 23 & 16 & 39 \\
\hline
\end{tabular}



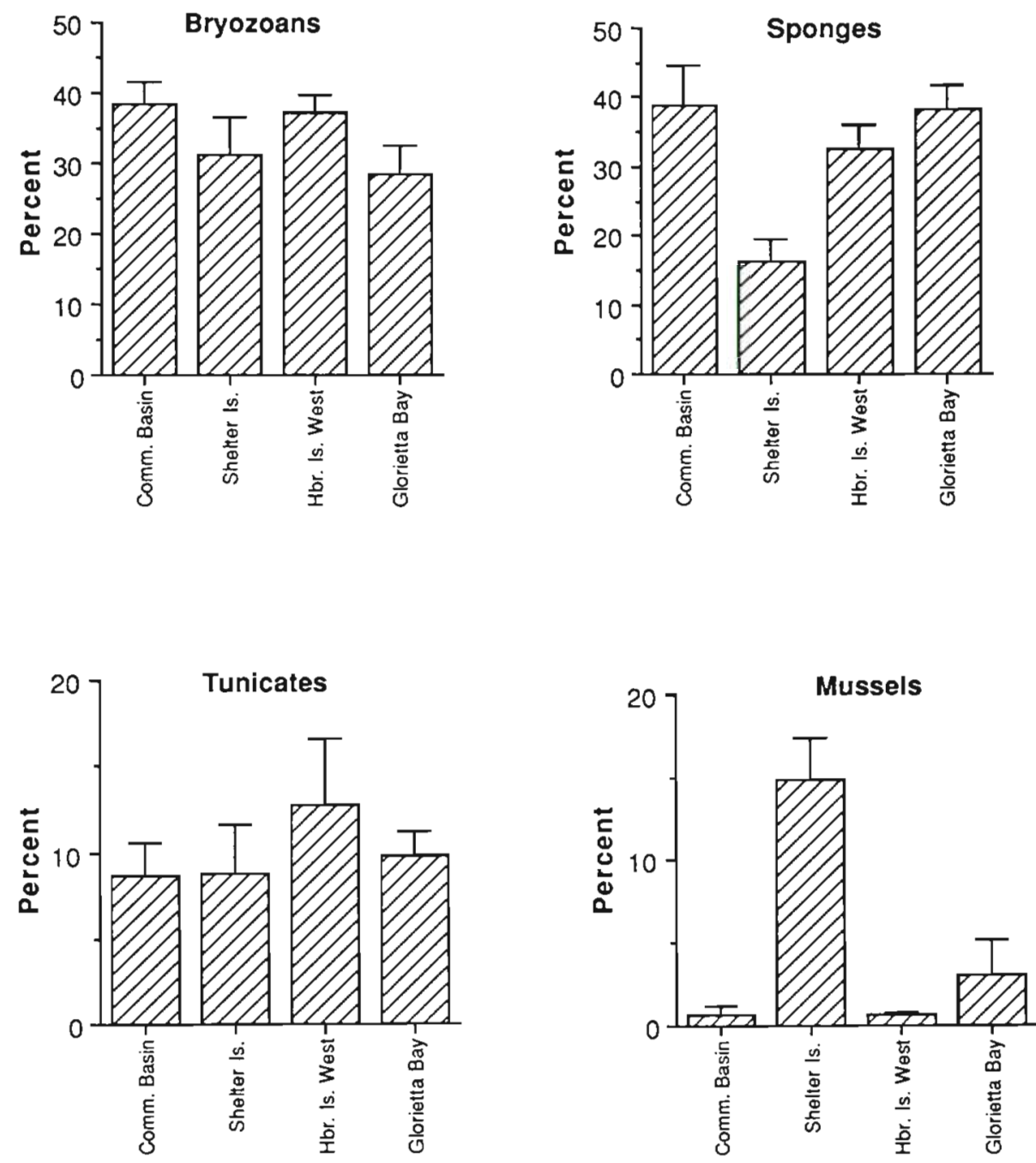

Fig. 6. Changes in percent cover of bryozoans, sponges, tunicates and mussels from hard bottom communities at the front of San Diego Bay embayments. Means and standard errors based on 10 replicate photographic samples per site

the front-bay stations. The one exception was serpulid worms at the front of Shelter Island, where they covered $20 \% \pm 12$ (SD). Serpulids accounted for less than $2 \%$ cover at the other 3 front-bay stations. Algae and the solitary tunicate Ciona intestinalis L., which were also characteristic of back-bay areas with many boats, accounted for less than $1 \%$ cover at the frontbay stations.

\section{TBT levels}

The concentration of TBT in water was greatest in embayments with many boats - Commercial Basin, Shelter Island, and Harbor Island West (Table 6), where levels were among the highest recorded in the world (Stephenson et al. 1988). TBT levels in back-bay areas with many boats were significantly greater than areas with relatively few boats (Mann-Whitney U-test, $\mathrm{p}<0.05, \mathrm{n}=3, \mathrm{n}=4$ ). TBT concentrations were also
Table 6. Ranges of tributyltin (TBT) levels in sea water in San Diego Bay embayments with many and few boats (the first value given in ranges is from August 1987 samples, second value from January 1988). Number of replicate TBT water samples in parentheses

\begin{tabular}{|lcc|}
\hline Embayment & $\begin{array}{c}\text { Back-bay TBT } \\
\text { in water }\left(\mu \mathrm{g} \mathrm{l}^{-1}\right)\end{array}$ & $\begin{array}{c}\text { Mid-bay TBT } \\
\text { in water }\left(\mu \mathrm{g} \mathrm{l}^{-1}\right)\end{array}$ \\
\hline Many boats & \multicolumn{2}{c}{ no data } \\
Commercial Basin & $400-180(4)$ & $190(1)$ \\
Shelter Island & $210,230(2)$ & $89(1)$ \\
Harbor Island West & $160(1)$ & $220,130(2)^{\circ}$ \\
Few boats & $16(1)$ & $18,42(2)$ \\
Harbor Island East & $81,86(2)$ & $45(1)$ \\
Glorietta Bay & $22,36(2)$ & $58,73(2)$ \\
Sweetwater Channel & $34,20(2)$ & \\
Naval Estuary & & \\
- New marina constructed in mid-bay area during the & \\
present study. Mid-bay samples taken in vicinity of newly \\
moored boats. Both samples taken in January 1988
\end{tabular}


greater in samples from back-bay compared to mid-bay areas for embayments with many boats. In contrast, 3 of the embayments with relatively few boats had higher TBT levels in mid-bay compared to back-bay areas (Table 6). The high value in mid-bay from Harbor Island East was adjacent to a newly constructed marina (Table 1). TBT water samples in Harbor Island East were taken after boats had begun to fill the marina. The slightly higher values in Sweetwater Channel and Naval Estuary may be caused by advection of more contaminated water from outside these embayments. The back-bay of Glorietta Bay contained a relatively small marina (Table 1), where TBT levels were higher than the mid-bay area (Table 6).

\section{DISCUSSION}

The presence of many boats in San Diego Bay embayments had a significant effect on the structure of hard-bottom communities living on floating docks. The backs of embayments with many boats generally had fewer species, less biomass, and lower cover of many sessile groups. Several groups characterized areas with many boats including serpulid polychaete worms, some solitary tunicates (Ciona sp.), and green and red filamentous macroalgae. These general community changes in embayments with many boats were also observed in qualitative surveys of other substrates in San Diego Bay and in harbors and marinas north of San Diego (also see Stallard et al. 1987). In contrast, the backs of embayments with few boats harbored a rich group of sessile invertebrates including sponges, bryozoans, tunicates, and mussels.

The dominance of serpulid polychaetes, filamentous algae, and other species may be related to tolerance of the physical and chemical conditions in embayments with many boats. Perhaps these species are less abundant in embayments with few boats because they are inferior competitors for space with groups such as sponges, bryozoans, mussels, and tunicates. For example, in other fouling communities tunicates are able to overgrow sponges, which overgrow bryozoans, which overgrow serpulids (Kay \& Keough 1981); and mussels are well-known competitive dominants in rocky intertidal communities (e.g Paine 1974, Menge 1976).

Animals nestling among the sessile organisms did not show changes in relative abundance that were related to many or few boats. Instead, the nestling crustaceans were extremely abundant in microhabitats including patches of filamentous red algae and dense forests of serpulid polychaetes. These microhabitat features were apparently more important to the abundance of nestlers than changes caused by many and few boats. In addition to an increase in number of individuals, the number of species was high in the same microhabitats. Nevertheless, the number of species of nestlers, both crustaceans and worms, was significantly greater in embayments with few boats compared to those with many boats.

The most likely alternative explanation of community changes between embayments with many and few boats is hydrography. The community patterns in backbays with many boats could be caused by relatively poor flushing or water circulation compared to backbays with few boats. This hypothesis is evaluated by comparing the observed community patterns to the hydrographic gradient along the main channel of San Diego Bay and to water exchange or flushing patterns within each embayment.

There is no relationship between community patterns and the occurrence of embayments along the hydrographic gradient from the mouth to the head of San Diego Bay (Fig. 1). The mouth of the bay is clearly better flushed than the head (Browning \& Speth 1973). Better flushing and exchange with marine waters is often accompanied by a greater variety of sessile invertebrates and macroalgae in estuaries and other coastal

Table 7. Distance from mouth of main channel, and geometric dimensions of embayments withın San. Diego Bay (SDB). These data are used as indicators of hydrographic conditions for comparisons of embayments with many and few boats. There are no correlations between hydrographic indices and biological data (see text)

\begin{tabular}{|c|c|c|c|c|}
\hline Embayment & $\begin{array}{c}\text { Distance into SDB } \\
\qquad(\mathrm{km})\end{array}$ & $\begin{array}{l}\text { Width of opening } \\
\qquad(\mathrm{m})\end{array}$ & $\begin{array}{l}\text { Width/length } \\
\text { (m) }\end{array}$ & $\begin{array}{c}\text { Area mouth/vol. SDB } \\
\qquad\left(\mathrm{m}^{2} / 10^{4} \mathrm{~m}^{3}\right)\end{array}$ \\
\hline \multicolumn{5}{|l|}{ Many boats } \\
\hline Commercial Basın & 4.4 & 285 & .523 & 8.0 \\
\hline Shelter Island & 2.7 & 154 & .277 & 2.7 \\
\hline Harbor Island West & 4.6 & 356 & .214 & 8.9 \\
\hline \multicolumn{5}{|l|}{ Few boats } \\
\hline Harbor Island East & 7.3 & 214 & .284 & 20.0 \\
\hline Glonetta Bay & 11.7 & 475 & .362 & 1.3 \\
\hline Sweetwater Channel & 17.6 & 119 & .281 & 8.7 \\
\hline Naval Estuary & 4.5 & 107 & 188 & 3.8 \\
\hline
\end{tabular}


embayments (Ricketts et al. 1985). Embayments with the greatest number of boats, such as Shelter Island and Commercial Basin, occurred nearest to the bay mouth (Fig. 1 and Table 1). Most of the embayments with few boats and well developed fouling communities were located furthest from the bay mouth: the opposite pattern to that predicted by the hypothesis that flushing along the main channel explains community patterns in back bay areas with many and few boats. There are no positive correlations (Spearman rank correlation test, $\mathrm{p}>0.05, \mathrm{n}=7$ ) between any of the biological data (percent cover, biomass, and species density) and the position of embayments along the hydrographic gradient of the channel (Table 7 ).

The shape of embayments and resulting variations in their hydrography are also unrelated to community patterns in back-bay areas with many and few boats. The width of the mouth, the length and width of the basin, and water depths influence the rate of tidal exchange or flushing of a harbor (Horn \& Allen 1976 , Cardwell \& Koons 1981). We examined the correlation between several indicators of water exchange and the structure of fouling communities. The indicators were width of opening, the ratio of width to length of basin, and the ratio of the area of the mouth to the volume of the basin (Table 7). These 3 flushing indicators were compared to total biomass (with and without the high value for serpulid polychaetes at Shelter Island), species density, and the cover of major groups (shown in Table 2). There were no significant correlations (Spearman rank correlation test, $\mathrm{p}>0.05, \mathrm{n}=7$ ).

All the front-bay sites were located along the main channel of San Diego Bay and were thus well flushed with bay water compared to all back-bay areas (see Fig. 1). Despite similar flushing patterns among embayments and the position of embayments along the hydrographic gradient of the main channel (Table 7), the front-bay communities (Fig. 6) were only similar to back-bay communities where there were few boats (Fig. 2 and 3). The natural experimental design cannot control for many other habitat features which may vary among embayments with many and few boats. Most anthropogenic chemicals are probably positively correlated with boat number. Since the hydrographic differences among embayments are not correlated with community patterns, there is no evidence that the natural characteristics of embayment water, such as primary production and particulate organic matter, are correlated with the observed community pattern. In contrast, when embayments are grouped by the number of boats they harbor (the natural experimental design used in the present study), there are consistent and statistically significant differences among embayments.

The high levels of TBT suggest that this chemical may be a cause of the change in community structure between embayments with many and few boats. However, in addition to TBT, other chemicals increase with many boats including other chemicals applied to boats (copper and zinc), oil and gas products, and many industrial compounds (PCB's and PNA's). Nevertheless, TBT is the most toxic chemical that has been introduced into the marine environment on purpose (Stallard et al. 1987). It is 100 to 1000 times more toxic than copper or zinc (Short \& Thrower 1986, Mayer 1987). Therefore, we hypothesize that TBT is a cause of community changes in sessile invertebrate assemblages between embayments with many and few boats. TBT does not explain the changes in nestling fauna, which were unrelated to boat number and thus TBT, but apparently dependent on biogenic habitat features.

The TBT hypothesis can be tested further by an experiment which was recently initiated when the California Department of Food and Agriculture banned TBT paints in California. The ban should lead to a significant decrease in TBT from embayments with many boats: the levels of other chemicals should remain relatively constant. If TBT primarily caused the community patterns in embayments with many boats, there should be a decrease in serpulid worms and filamentous algae and an increase in many sessile invertebrates as the levels of TBT decrease. In addition, TBT paints may become more common in countries with less regulation such as Mexico. Changes in the use of TBT may provide unique natural experiments that help isolate important anthropogenic impacts, a prerequisite to improving habitat values in harbors.

Acknowledgements. We thank J. Boland, S. Kim, J. Oakden, J. Oliver, C. Oliver, P. Slattery, and D. Watters for field help; and Mike Foster and Ken Johnson for improving the presentation. Thanks for the support of the California State Water Resources Control Board, M. Martin and especially P. Michaels and D. Jean.

\section{LITERATURE CITED}

Alzieu, C. (1981). Evaluation des risques dues a l'emploi des peinture anti-salissures dans les zones conchylicoles. Anomalies de calcification. Theme surveillence continue mecanismer dactrion des pollutants. Addendum du rapport due 15 Juin 1981. Institute Scientifique et Technique des Pêches Maritimes Nantes

Alzieu, C., Thibaud, Y., Heral, M., Boutier, B. (1980). Evaluation des risques dus a l'emploi de peintures anti-salissures dans les zones conchylicoles. Revue. Trav. Inst. (Scient. tech.) Pêch. marit. 44: 301-349

Beaumont, A. R., Budd, M. D. (1984). High mortality of the larvae of the common mussel at low concentrations of tributyltin. Mar. Poll. Bull. 15: 402-405

Beaumont, A. R., Newman, P. B. (1986). Low levels of tributyltin reduce growth of marine mirco-algae. Mar Pollut. Bull. 17: $457-461$

Browning, B. M., Speth, J. W. (1973). The natural resources of 
San Diego Bay: their status and future. Calif. Fish Game Coastal Wetlands Series 5

Bryan, G. W., Gibbs, P. E., Burt, G. R., Hummerstone, L. G. (1987). Effects of tributyltin. (TBT) accumulation on adult dog-whelks, Nucella lapillus: long-term field and laboratory experiments, J. mar biol. Ass. U.K. 67. 525-544

Capuzzo, J. M., Kester, D. R. (1987). Biological effects of waste disposal: experimental results and predictive assessments In: Capuzzo, J. M., Kester, D. R. (eds.) Oceanic processes in marine polution. R. E. Krieger Publishing Co., Malabar, Florida, p. 3-11

Cardwell, R. D., Koons, R. R. (1981). Biological consideration for the siting and design of marinas and affiliated structures in Puget Sound. Tech. Rep. no. 60. Washington State Department of Fisheries, Olympia, Washington

Champ, M. A., Lowenstein, F. L. (1987). TBT: the dilemma of high technology antifouling paints. Oceanus 30: 69-77

Clavell, C., Seligman, P. F., Stang, P. F. (1986). Automated analysis of organotin compounds: a method for monitoring butyltins in the marine environment. In: Champ, M. A. (ed.) International Organotin Symposium, Ocean's 86 Symposium, Washington, D. C., p. 1152-1154

Cleary, J. J., Stebbing, A. R. D. (1987). Organotin in the sur. face microlayer and subsurface waters of Southwest England. Mar. Pollut. Bull. 18: 238-246

Connell, J. H. (1972). Community interactions on marine rocky intertidal shores. A. Rev. Ecol. Syst. 3: 169-192

Dayton, P. K., Oliver, J. S. (1980). An evaluation of population and community patterns in the benthic marine environment. In: Tenore, K. R., Coull, B. C. (eds.) Benthic dynamics. The Belle W. Baruch Library in Marine Science, number 11, Georgetown, South Carolina, p. 93-120

Fager, E. W. (1968). A sand-bottom epifaunal community of invertebrates in shallow water Limnol. Oceanogr 13: $448-464$

Gibbs, P. E., Bryan, G. W (1986). Reproductive failure in populations of the dog-whelk, Nucella lapillus, caused by imposex induced by tributyltin from antifouling paints. J. mar biol. Ass. U.K. 66:767-777

Gibbs, P. E., Bryan, G. W., Pascoe, P. L., Burt, G. R. (1987). The use of dog-whelks, Nucella lapillus: long term field and laboratory experiments J. mar biol. Ass. U.K. 67: 525-544

Gray, J.S., Aschan, M., Carr, M. R., Clarke, K. R., Green, R. H., Pearson, T H., Rosenberg, R., Warwick, R. M. (1988). Analysis of community attributes of the benthic marcofauna of Frierfjord/Langesundfjord and in a mesocosm experiment. Mar Ecol. Prog. Ser. 46: 151-165

Hall, L. W., Jr, Lenkevich, M. J., Hall, W. S., Pinkney, A. E., Bushong, S. J. (1986). Monitoring organotin concentrations in Maryland waters of Chesapeake Bay. In: Champ, M. A. (ed.) International Organotin Symposium, Ocean's 86 Symposium. Washington, D. C., p. 1275-1279

Horn, M. H., Allen, L. G. (1976). Numbers of species and faunal resemblance of marine fishes in California bays and estuaries. Bull. Sth. Calif. Acad. Sci. 75 (2): 159-170

Hurlbert. S. H. (1984). Pseudoreplication and the design of ecological field experiments. Ecol. Monogr 54: 187-212

Kay, A. M., Keough, M. J. (1981). Occupation of patches in the epifaunal communities on pier pilings and the bivalve Pinna biolor at Edithburgh, South Australia. Oecologia (Berl.) 48: 123-130

Langston, W. J., Burt, G. R., Zhou Mingjiang (1987). Tin and organotin in water, sediments, and benthic organisms of Poole Harbour. Mar. Pollut. Bull. 18: 634-639

Light, S. F. (1975). Light's manual: intertidal invertebrates of the Central Calif. Coast. In: Smith, R. I., Carlton, J. I (eds.) University of California Press, Berkeley
Mayer, F. L. (1987). Acute toxicity of chemicals to estuarine organisms. U.S. Environmental Protection Agency Report 600/8-87/017

Menge, B. A. (1976). Organization of the New England rocky intertidal community: role of predation, competition, and environmental heterogeneity. Ecol. Monogr. 46: 355-393

Paine, R. I (1974). Intertidal community structure: experimental studies on the relationship between a dominant competitor and its principal predator. Oecologia (Berl.) 15: 93-120

Phillips, P. T. (1988). California State Mussel Watch ten year data summary 1977-1987. Water quality Monitoring Report No. 87-3 Division of Water Quality. California State Water Resources Control Board

Ricketts, E. F., Calvin, J., Hedgpeth, J. W (1985). Between Pacific tides. Stanford University Press, Stanford

Reish, D. J., Soule, D. F., Soule, J. D. (1980). The benthic biological conditions of the Los Angeles-Long Beach Harbors: results of 28 years of investigations and monitoring. Helgoländer Meeresunters. 34: 193-205

Salazar, M. H., Salazar, S. M. (1987). Tributyltin effects on juvenile mussels growth. In: Champ, M. A. (ed.) International Organotin Symposium, Vol. 4, Ocean's 87 Symposium, Halifax, Nova Scotia, p. 1504-1510

San Diego Unified Port District (1988). San Diego Bay boat and slip count 21 March, 1988. Bay Control Office, San Diego Unified Port District, San Diego, California

Seligman, P. F., Grovhoug, J. G., Richter, K. E. (1986). Measurements of butyltins in San Diego Bay, Ca.: a monitoring strategy. In: Champ, M. A (ed.) International Organotin Symposium, Ocean's 86 Symposium, Washington, D. C., p. $1289-1296$

Short, J. W., Thrower, F. P. (1986). Tributyltin caused mortality of chinook salmon, Oncorhynchus tshawytscha, on transfer to a TBT-treated marine net pen. In: Champ, M. A (ed.) International Organotin Symposium, Ocean's 86 Symposium, Washington, D. C., p. 1202-1205

Stallard, M., Hodge, V., Goldberg, E. D. (1987). TBT in California coastal waters: monitoring assessment. Envir Monitg. Assessmt 9: 195-220

Stang, P. M., Seligman, P. F. (1986). Distribution and fate of butyltin compounds in the sediment of San Diego Bay. In: Champ, M. A. (ed.) International Organotin Symposium, Ocean's 86 Symposium, Washington, D. C., p. 1256-1261

Stephenson, M. D., Aronson, L. J., Goetzl, J. D., Ichikawa, G. S., Paulson, K. S., Warren, D. W., Martin, M. (1988) TBT effects on Oysters. Report submitted to The Californian State Regional Water Quality Control Board, San Diego

Stephenson, M. D., Smith, D. R., Goetzl, J. D., Ichikawa, G. S., Martin, M. (1986). Growth abnormalities in mussels and oysters from areas with levels of tributyltin in San Diego Bay. In: Champ, M. A. (ed.) International Organotin Symposium, Ocean's 86 Symposium, Washington, D.C., p. 1246-1251

Stromgren, T., Bongard, T (1987). The effects of tributyltin oxide on growth of Mytilus edulis. Mar Pollut. Bull. 18: $30-31$

Stull, J. K., Haydock, C. I., Smith, R. W., Montagne, D. E. (1986). Long-term changes in the benthic community on the coastal shelf of Palos-Verdes Southern California, USA. Mar Biol. 91 539-552

Swartz, R. C., Cole, F. A., Schults, D. W., DeBen, W. A. (1986). Ecological changes in the Southern Californı Bight near a large sewage outfall: benthic conditions in 1980 and 1983 Mar. Ecol. Prog. Ser. 31: 1-13

Thain, J. E. (1983). The acute toxicity of bis (tributyltin) oxide 
to the adults and larvae of some marine organisms. Int. Counc. Explor. Sea Comm. Meet. (Pelagic Fish Comm.) E: 13: $1-5$

Thain, J. E., Waldock, M. J. (1986). The impact of tributyltin (TBT) antifouling paints on molluscan fisheries. Wat. Sci. Tech. 18: 193-202

U'Ren, S. C. (1983). Acute toxicity of Bis (tributyltin) oxide to a marine copepod. Mar. Pollut. Bull. 14: 303-306

Valkirs, A. O., Davidson, B., Seligman, P. (1985). Sublethal growth effects and mortality to marine bivalves and fish from long-term exposure to tributyltin. Naval Oceans System center TR 1042, San Diego, California

Valkirs, A. O., Seligman, P. F., Stang, P. F., Homer, V., Lieber-

This article was submitted to the editor man, G. V., Dooley, C. A. (1986). Measurement of butyltin compounds in San Diego Bay. Mar. Pollut. Bull. 17. 319-324

Waldock, M. J., Thain, J. E. (1983). Shell thickening in Crassostrea gigas: organotin antifouling or sediment induced? Mar Pollut. Bull. 14: 411-416

Waldock, M. J., Thain, J. E., Waites, M. E. (1987). The distribution and potential toxic effects of TBT in UK estuaries during 1986. Appl. org. Chem. 1. 287-301

Walsh, G. E., McLaughlin, L. L., Lores, E. M., Louie, M. K., Deans, C. H. (1985). Effects of organotins on growth and survival of two marine diatoms Skeletonema costatum and Thalassiosira pseudonana. Chemosphere (U.K.) 14: 383-392

Manuscript first received: March 31, 1989

Revised version accepted: October 2, 1989 